\title{
The petro-political configuration: entanglements of Western and Chinese oil zones in Niger
}

DOI 10.1515/zfw-2015-0583

Abstract: The article examines the spatial, economic, political and socio-cultural transformations induced in the process of Niger becoming a new oil producer in 2011. It does so by analyzing entanglements of Western and Chinese 'oil zones' in Niger, which are understood as trans-territorial spaces of assemblage. I argue that the specific properties of these two oil zones have triggered the emergence of a particular 'petro-political configuration' in Niger. The argument proceeds through four stages. Firstly, looking at economic entanglements, I argue that the Chinese oil zone enabled the Nigerien economy to develop so-called upstream and downstream oil industries, something the Western oil zone had not allowed. Secondly, analyzing political and socio-cultural entanglements, I argue that, by being co-opted into former Nigerien president Mamadou Tandja's political project for constitutional amendment, China's oil diplomacy has become a kind of 'soft power' in Niger, something Western political rhetoric has failed to achieve. Thirdly, focusing on geopolitical and military entanglements, I argue that the militarization of global space should ensure capitalist accumulation, especially in situations in which the translation of transnational governmentality has failed. Finally, I use these entanglements to identify the heterogeneous elements of Western and Chinese 'oil zones', and the specific capitalist properties these assemblages generate.

Keywords: assemblage, China, infrastructure, oil, politics, Niger.

Articel note: Parts of this paper were taken from my Nigerien example in a book chapter I co-authored with Andrea Behrends: Schritt, J./Behrends, A. (forthcoming): 'Western' and 'Chinese' Oil Zones. Petro-Infrastructures and the emergence of new trans-territorial spaces of order in Niger and Chad. In: Engel, U./Müller-Mahn, D./ Böckler, M. (Hrsg.): Spaces of Order: Adaptation and Creativity in Africa.

*Corresponding author: Jannik Schritt, Institute for Social and Cultural Anthropology, Georg August University of Göttingen, Theaterplatz 15, 37073 Göttingen, Germany, e-mail: jschrit@uni-goettingen.de

\section{Introduction}

Since the end of the Cold War in 1989, and with the rise of new emergent powers in the world, Africa has become increasingly important in the competition for oil, especially between Western and Chinese oil companies. This competition was fueled by high oil prices on the world market (between 2004 and 2014), and political instability in the Middle East that shifted the attention to hitherto underexplored regions in Africa. Pointing to the similarities and continuities of colonial exploitation in Africa, many academics and journalists have coined this competition a 'new scramble for African oil' (Ghazvinian 2007; Klare/ Volman 2006; Yates 2012). In doing so, however, these critics neglect the new agency of African states after independence and the end of the Cold War (Frynas/Paulo 2007). It is through this agency and the increasing competition for African oil that many African countries became new oil producing states (Hicks 2015). ${ }^{1}$ One of these new oil producers is the landlocked West-African country, Niger. In 2008, the China National Petroleum Corporation (CNPC) signed a Production Sharing Agreement (PSA) with the Nigerien government. The agreement included a condition to construct an oil refinery with a capacity of 20,000 barrels per day (bpd) within the national territory. ExxonMobil and Petronas had rejected this condition, and in 2006, abandoned oil exploration in Niger, judging the country's estimated oil reserves not to be economically profitable. Finally, in 2011, the CNPC and Nigerien government inaugurated the joint-venture oil refinery near Niger's second largest city, Zinder, in the country's east.

The historical conjuncture of Niger becoming a new oil producer offers a unique opportunity to analyze the economic, political and socio-cultural transformation processes induced by entanglements of 'Western' and 'Chinese' oil zones. I understand these zones as trans-territorial spaces of order which have varying properties. I will argue that the different characteristics of these two oil zones, in their entanglement with the Nigerien context, have triggered different spatial, economic, political and cultural transformation processes. First, by looking

1 With the recent fall in oil prices, some countries (including Uganda, Kenya, and Tanzania) are still waiting to start producing oil. 
at the economic entanglements of 'Western' and 'Chinese' oil zones in Niger, I will show that the Western oil zone's neoliberal properties - which could be characterized as 'points of profit' or the 'enclave approach' - divide Niger according to the old (French) colonial classifications of Afrique utile, the economically useful, and Afrique inutile, the economically worthless (Ferguson 2005). In contrast to the 'Western' oil zone, I will show that the Chinese oil zone's state capitalist properties have enabled the Nigerien economy to develop so-called upstream and downstream oil industries - not only for extraction of the oil, but also for the refinement, use, and sale of it within Africa. The Chinese oil zone engages in large-scale industrialization and infrastructure modernization projects, promoting the build-up of network-style spatial connections and linkages in Afrique inutile itself. Second, analyzing the political and socio-cultural entanglements of these two oil zones, I will show that by articulating China's oil diplomacy of 'equal partnership', 'win-win relationships' and 'non-interference' with the former Nigerien president Mamadou Tandja's political project for constitutional amendment in 2010, China's political rhetoric became a kind of 'soft power' in Niger. In contrast to China's oil diplomacy, I argue that the translation of Western transnational governmentality in Niger has largely failed because Western politics are portrayed as neo-colonial and ineffective in promoting national development (Schritt 2013). Third, by focusing on the geopolitical and military entanglements of these two zones in Niger, I will show that the military approaches of China and the West (the USA and France) abroad differ in such a way that we might speak of a 'soft' (Chinese) and a 'hard' military strategy (American and French) (Sun 2015). Nevertheless, it is important to note that the Chinese military presence is constantly growing in Africa, and these two approaches appear to be converging. Finally, I summarize the diverse entanglements of the Western and the Chinese zones with the Nigerien state, sketching out how the heterogeneous elements of these two zones - which emerge in relational, overlapping, conflicting, competing and cooperative forms - reveal particular varieties of capitalism. In connecting these arguments to contemporary academic literature, I contextualize the Niger case study in broader debates about 'China in Africa' and 'the oil industry'.

\section{The petro-political configuration}

Since the 1990s, scholarly debate about oil has been dominated by the resource curse thesis and rentier state theory.
In broad terms, these theories forecast that the production of oil leads to economic decline, enclave industrialization, the emergence of authoritarian regimes, violent conflicts, corruption, a rent-seeking mentality and environmental pollution (Gelb 1988; Auty 1993; Yates 1996; Karl 1997; Ross 2012). Literally thousands of studies on oil producing nations across the globe have investigated these concepts (especially the resource curse thesis). Some social sciences approaches have made use of the resource curse and rentier state models, but have also argued for placing oil production in the context of pre-existing social and political structures (Behrends/Reyna/Schlee 2011; Watts 2004). In recent years, social scientists have been increasingly dissatisfied with the models' dominant focus on oil as money (Watts 2004; Mitchell 2011). From the beginning, anthropological approaches have pointed to the importance of the production of meanings or significations of oil (Behrends/Schareika 2010) that are essential in constructing a new oil reality, be it in state-building processes (Coronil 1997), cultural production (Apter 2005), conflicts (Behrends 2008) or political disputes (Schritt 2014). In addition to significations approaches, science and technology studies (STS) and the 'material turn' have gained high currency in the social sciences, especially in geography, sociology, history and anthropology. In thinking oil beyond the 'resource curse', these approaches seek to account for forms of agency and control contained in the materiality of the resource (oil), and the technological as well as socio-political infrastructures surrounding oil production (Mitchell 2011; Rogers 2012; Barry 2006, 2013; Appel 2012a, 2012b; Watts 2012; Richardson/Weszkalnys 2014).

Instead of analyzing the different dimensions of oil production separately - money, significations, materiality, infrastructure - scholars have tried to combine these different 'sensitizing concepts' (Blumer 1954) into new analytical ones. Dominic Boyer, for example, proposed the concepts 'energopolitics' (2011) or 'energopower' (in the style of Foucault's 'biopower') in order to ask how 'energic forces and infrastructures interrelate with institutions and ideations of political power' (2014:309). Other scholars have made use of the concept of 'oil assemblage' in order to point to the multiplicity and heterogeneity of oil's manifestations (Appel/Mason/Watts 2015).

In this paper, I build on these new analytical concepts to analyze how the heterogeneous elements of trans-territorial spaces that are oil assemblages entangle with the $\mathrm{Ni}$ gerien context and form what I call the 'petro-political configuration'. Such a configuration is a network of economic, (geo)political, spatial and socio-cultural elements of politics and oil production that emerges as an entity with particular properties. Whereas each element is self-contained 
and exists autonomously from the conceptions we have of it (DeLanda 2006), not only has each part a 'vital force', but the grouping itself also enacts an 'agency of assemblage' (Bennett 2010:24) or 'causal power' that exceeds the sum of the single components. In using the term causal power, I refer to specific inward oriented (governmentality and the necessity of profit-maximization inherent to capitalism) and outward oriented forces (transnational governmentality and capitalist processes of accumulation). Indeed, as (oil) assemblages are always global in scale (Collier/Ong 2005), we have to account for trans-territorial entanglements that involve superpowers, transnational companies, economic theories and so on. In analyzing these entanglements, we need a multi-scalar approach which should allow us to conceptualize scales not as pre-existing frames (global, national, local) but as aggravated effects of networking practices (Callon/Latour 1981; Legg 2009, 240).

This perspective resonates with the regulation school (Hirsch/Jessop/Poulantzas 2001) that first emerged in France in the mid-1970s (Aglietta 1976), but also came to prominence in Germany (Hirsch 1990) and Great Britain (Jessop 2007). Classical Marxist approaches analyze how the economic base (mode of production) determines the political superstructure (state). In contrast, the regulation school considers a dialectic of base and superstructure, asking how the capitalist regime of accumulation is stabilized through political and socio-cultural regulation, namely the institutions and norms that generate individual and collective behavior which fit the historical conditions of accumulation. It further resonates with the "varieties of capitalism' (VoC) approach (Hall/Soskice 2001) which tries to analyze the institutional foundations of comparative advantage in explaining differences between national capitalisms. Both approaches have been rightly criticized for their methodological nationalisms (Peck/ Theodore 2007), which need to be overcome by multi-scalar analysis (Klimek 2010). The difference between an assemblage approach and these (Marxist) political economy approaches is primarily an ontological one. Whereas a dialectic approach of base and superstructure sticks to a 'deep ontology', an assemblage approach follows a 'flat', or better 'relational ontology', which considers the heterogeneous elements symmetrically, and asks what kind of (capitalist) wholes emerge through associations between these elements. In the following section, I explore how elements of Western and Chinese oil production associate with elements of the Nigerien context to emerge as a 'petro-political configuration'. I then use the diverse entanglements of Western and Chinese oil engagement in Niger to sketch the heterogeneous elements and the particular properties of these two different 'oil zones'.

\section{The economic, political and military context in Niger}

Economically, Niger is one of the poorest countries in the world. It is characterized by cycles of drought and famine, strong population growth, scarce arable land and degraded fertile soil. Niger also has low levels of productivity and technology and is highly dependent on foreign investment and development aid. These economic characteristics have a long history, and remain largely unchanged, even today (Charlick 1991, 89). ${ }^{2}$ The French colonizer's - who had long classified Niger as Afrique inutile - economic policy was purely exploitative, and aimed at keeping administrative costs to a minimum. Thus, the colonial government made small to no investments in infrastructure development (ibid.). Even today, infrastructure development in postcolonial Niger remains largely dependent on foreign investment. Prior to the beginning of oil production in 2011, Niger lacked sufficient energy supplies, and was dependent on expensive imports of oil (especially from Venezuela) and hydroelectric power (from Nigeria). In this context, a longstanding desire for energy autonomy (especially nuclear energy and fossil fuels) has existed in Niger, especially as uranium was found in 1956, and oil exploration had begun as early as 1958.

Politically, until the early 1990s, Niger was ruled by authoritarian regimes: Hamani Diori (1960-1974), Seyni Kountché (1974-1987) and Ali Saibou (1987-1990). The foundations of these autocracies had been laid by French colonial intervention to secure access to Niger's uranium reserves in the late 1950s (van Walraven 2009). After independence in 1960, the political dynamics of post-colonial Niger went hand in hand with the country's political economy (Robinson 1991; Idrissa 2001). First, there was the groundnut economy (1960-1974) which was a legacy of the colonial era; second, the boom and bust cycles of the uranium-based economy (1974-1990); third, the economic crisis and political instability (1990-2000) that came with the introduction of structural adjustment programs and a transition to a multi-party system; and fourth, debt relief and new economic stability under President Mamadou Tandja (2000-2010) (Dorlöchter-Sulser 2014, 137-149). During the authoritarian regimes, the revenues from primary commodity exports (first from groundnut and later from uranium) were used to build clientelist networks, whose base was threatened with collapse each time the

2 This is not to say that the livelihood systems in Niger have not changed. Indeed, in adapting to Niger's changing structures of political economy, they have diversified and changed in manifold ways (Dorlöchter-Sulser 2014). 
financial leverage of the government shrank. This led to the 1974 military coup against the first Nigerien president, Hamani Diori, when shrinking revenues from groundnut production led to a disintegration of Diori's clientielist base, and internal conflicts within his political party began to emerge. In 1990, with narrow financial leverage due to austerity measures imposed by the IMF in the wake of the Structural Adjustment Programs, General Ali Saibou was forced to agree to a National Conference and a democratic transition. The reintroduction of a multi-party system in Niger gave rise to a decade of experimentation and repetitive breakdowns of the institutional order (Villalón/ Idrissa 2005). The rules of the game had changed. The political game was no longer one of simply defusing internal party conflicts in a one-party or no-party state. Rather, political competition and strategic conflicts between the opposition and the government majority became an integral part of the game, with new social (civil society associations and labor unions) and political actors (political parties) emerging. The 2008 oil project agreement was signed in this context, and was immediately put to use in political disputes (Schritt 2014).

Militarily, strong ties with France from the colonial era persist. France's agreement to decolonize Niger had been realized through secret military arrangements, resource agreements and special monetary zones which serve to secure France's energy security (Sharife 2010; Hecht 2012, chapter 4\&7). In 1961, one year after its independence, Niger signed a defense treaty which granted the former colonizer priority access to uranium and other strategic materials. Moreover, the defense treaty assured that the French would retain a profound influence on Niger's military (Mahamane 2004), an influence which continues to shape the whole Nigerien military and political landscape (Idrissa 2004). Although the military involvement of China and the USA in Niger is growing constantly, even today France provides the largest share of military assistance to Niger.

\section{Assembling economics - building linkages}

Before the oil contract between the Nigerien government and China National Petroleum Corporation was signed in June 2008, Niger had already had a 50-year history of oil exploration. Explorations, mainly by French and American based oil companies, began in 1958 following the first major oil discoveries in neighboring Algeria two years prior. With the beginning of commercial oil exploitation in
Chad in 2003, and the construction of the Chad-Cameroun pipeline, oil exploration in Niger became economically more interesting, as oil from Niger could then be pumped through the pipeline. ${ }^{3}$ The economic profitability of oil also skyrocketed, with an increase in the price per barrel from \$US30 in 2006 to \$US147 in 2008 (Moussa 2012). Nevertheless, in 2006, ESSO and Petronas had abandoned the oil block Agadem because they refused to build an oil refinery that the Nigerien government, under then President Tandja, had made a condition for concluding an oil contract with Niger. Given the Nigerien government's conditions, the low oil price in 2006 and the small estimated quantity of the oil reserves, the oil majors had judged the oil reserves to be economically unprofitable. ${ }^{4}$ Here it is important to note that Western oil companies are multinational enterprises and thus capitalist players. Their goal is not to develop untapped oil reserves, but rather the maximization of profit in a setting of economic competition. The logic of capitalist accumulation needs to turn oil's abundance into (a rhetoric of) scarcity on the world market in order to maintain high prices (Labban 2008). The world history of oil has therefore not been driven by great explorers seeking to make ever more oil accessible to mankind (cf. Yergin 1991), but has rather been characterized by oil companies delaying the discovery of untapped oil reserves (Mitchell 2011). This is especially true for the landlocked Sahel-Saharan countries like Niger, which remain under-explored today (Augé 2011/3).

The condition set by the Nigerien government to build an oil refinery within the territory of Niger was, however, met by the CNPC. With this agreement, CNPC set out to start a more comprehensive industrial project. This project has different properties than the Western oil zone, in which the valuable energy resource is simply transferred to centers of industrial production and consumption in the USA or Europe. With the company's agreement to build an oil refinery, the CNPC leaves much of the energy produced to be used for industrial production and final consumption in Niger. This facilitates the development of so-called backward and forward linkages, which promote

3 For background on the negotiations over connecting the Western and the Chinese technological zones in Chad, see van Vliet/Magrin (2012).

4 Official estimates made by ESSO and PETRONAS stated that the quantity of oil reserves in the Agadem oil block was up to 324 million barrels and 10 billion $\mathrm{m}^{3}$ of gas. After signing the oil contract, the CNPC immediately revised these estimations up to 744 million barrels of oil and 16 billion $\mathrm{m}^{3}$ of gas. The latest estimates are as high as one billion barrels. Nevertheless, the Nigerien oil reserves are still low in comparison to the oil reserves in major African oil-producing countries (Algeria, Libya, Nigeria and Angola). 


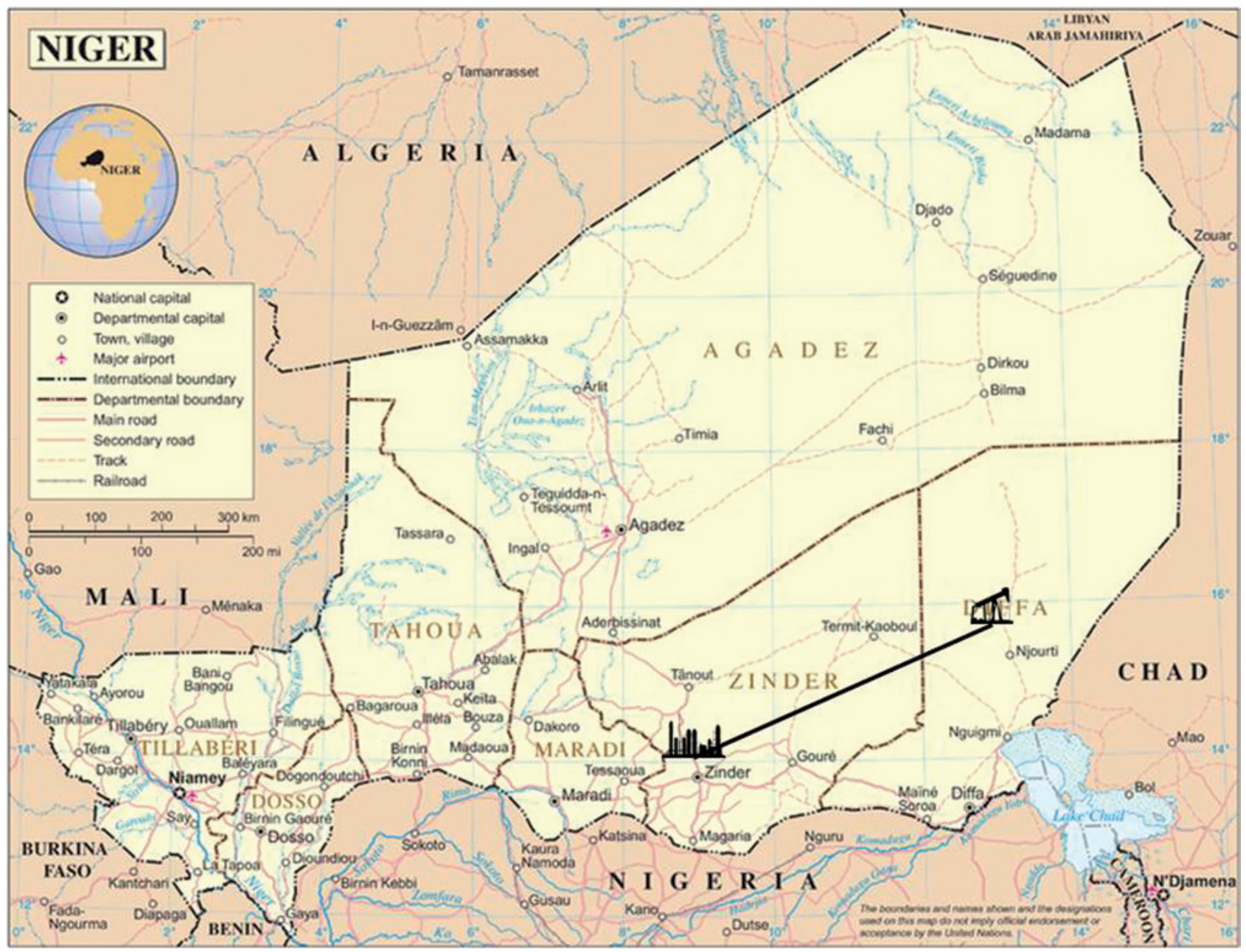

Map 1: Oil production in Niger. Source: own illustration based on UN map of Niger, found at www.un.org/Depts/Cartographic/map/profile/niger.pdf.

economic development and help tentatively overcome enclave industrialization. With Hirschman (1981), I understand linkages as a closely-knit regional network consisting of several forms of connections. These linkages are manifold: first, forward linkages through the further processing of resources within the region; second, backward linkages through the additional manufacture of intermediate products derived from the resource in question as inputs of production; third, consumption linkages through the generation of consumer demands resulting from new employment and income possibilities; fourth, fiscal linkages as the result of additional state revenues that are to be spent on regional development. Without these production linkages, the resources are simply exported to and processed within the industrial centers of the world, while the regions of resource extraction remain 'black holes' (cf. Innis 1995). ${ }^{5}$

On 2 June 2008, CNPC and Niger signed integrated upstream and downstream deals for the Agadem oil block in the far east of Niger. The agreement involved oilfield exploration and the development of a 20,000 bpd oilfield (the Gouméri, Sokor and Agadi oil deposits that were discovered by ESSO in 1982, 1990 and 1994 respectively), a 20,000 bpd joint venture refinery in Zinder, and the construction and operation of a $462.5 \mathrm{~km}$ pipeline connecting the oil fields to the refinery (see map 1). Owned by the Société de Raffinage de Zinder (SORAZ) with $60 \%$ Chinese and $40 \%$ Nigerien shareholdings, the refinery near

5 I primarily use Hirschman's 'linkage model' in a descriptive way to illustrate the associations and connections that result from the implementation of the Chinese built petro-infrastructure in Niger, rather than as a clear-cut development theory. 
Zinder has a central power station and produces 20,000 bpd of gasoline (34\%), diesel (56\%), fuel oil (3\% used by the refinery), and Liquefied Petroleum Gas (LPG) (7\%) respectively. These fuels are first used to supply the Nigerien domestic market, which consumes approximately 7000 bpd of gasoline. The surplus 13,000 bpd are exported to neighboring countries, especially Nigeria, Mali and Burkina Faso.

The CNPC paid the Nigerien government a $\$$ US300 million signing fee. On 28 November 2011, the Agadem upstream and downstream integrated project was completed and became operational. The cost of the oil refinery, about \$US980 million, was financed by a loan with a repayment term of 10 years from China's EXIM Bank. The pipeline costs amounted to approximately \$US348 million. Since 2012, government revenues from the integrated oil project have been slightly over \$US100 million annually. Although Niger does not yet export crude oil, the fiscal linkages from Nigerien oil production have already slightly exceeded the annual revenues from uranium extraction by AREVA/ France which have made Niger the world's fourth largest uranium producer. In 2015, former secretary general of Niger's oil ministry and new president of the African Petroleum Producers Association (APPA) Mahaman Laouan Gaya predicted that all (African) oil producers, with the exception of Niger, will go into economic recession in the next years due to falling oil prices. Niger is said to be experiencing a slightly positive economic upturn from falling prices, as it refines its whole production within the national territory, and is yet to export any of its crude oil (at the time of writing in 2016) (Gaya 2015). ${ }^{6}$

However, with the recent fall in oil prices, a long-standing conflict between Chinese-Nigerien joint venture SORAZ and the Nigerien state-owned company SONIDEP, which is in charge of stocking and distributing the oil products, flared up once again. On 14 August 2015, SORAZ stopped the oil refinery due to a reported compressor failure. However, analysts on national and international news platforms (see for example, tamtaminfo.com and africaintelligence.com) quickly interpreted the refinery's shutdown as a decision by CNPC to pressure the Nigerien government to acquiesce to demands for a bigger share of export revenues from refined oil products. According to these analysts, with the oil price crashing to under \$US50 a barrel in mid-2015, SORAZ moved into the red because it had agreed on a fixed price with CNPC to purchase the barrel at about \$US70. CNPC's insistence, Rosen (2015) argues, "on selling at above the market price - even to a

6 Export of crude oil is expected to start in 2017, although it is doubtful whether this early date is realistic. refinery for which it is itself the majority stakeholder - is an effort to impose authoritarian certainty on inherently unstable markets". In this process, SORAZ accused SONIDEP of large outstanding debts (\$US68 million) which SONIDEP however denied.

The conflict shows that SORAZ wants to be in charge of the decision-making on the sales of their products, and is therefore claiming that SONIDEP is posing another burden on the fuel price in Niger. ${ }^{7}$ Without SONIDEP however, the government of Niger would find it difficult to control the quantity of oil products sold, and capital flight for the CNPC, as shareholder in SORAZ, would become significantly easier. In addition, SONIDEP ensures Niger's fuel supply, and is thus vital to the country's energy security. A similar incident between SORAZ and SONIDEP took place in 2012, when SORAZ stopped production for maintenance work, creating fuel shortages in Niger and revealing that SONIDEP had not fulfilled their duty to stock and supply fuel. For several days, the fuel price rose from about 600 FCFA/liter to over 1000 FCFA/liter on the informal market in the capital city, Niamey.

The construction of the oil refinery at Zinder triggered the emergence of new, Nigerien based transport companies owned by individual businessmen. In addition, since the beginning of the operational phase of the oil refinery, more than one hundred private petrol stations have sprouted up like mushrooms in the greater region of the capital, where about $80 \%$ of Niger's consumption of petroleum products is located. Stations have also popped up in other urban centers along the two main trunk roads headed north and east from Niamey. In April 2013, Niger had a total of 497 open gas stations, of which 117 had been newly opened in Niamey, with an annual growth rate of $25 \%$ (Xinhua News Agency 2013). In the city of Zinder, the number of petrol stations had increased from six in 2011 to 21 by October 2015. In the city of Diffa, the overall number of petrol stations had increased from two to four, while no new petrol stations had been set up in N'guigmi, the town closest to the oil extraction zone. However, the majority of the population in eastern Niger continues to buy smuggled fuel from Nigeria, which is currently sold at $600 \mathrm{FCFA} /$ liter $^{8}$ (compared to $540 \mathrm{FCFA} /$ liter at the pet-

7 The fuel price at SORAZ is about 350 FCFA/liter. With taxes, transport costs and charges of SONIDEP, consumers have to pay 540 FCFA/ liter at the petrol stations.

8 The fuel is smuggled over the Nigerien-Nigerian border in cars packed full of 501-brand jerry cans. The dealers fill the jerry cans at regular petrol stations and then cross the border by bypassing the border checkpoints. The street fuel price is highly dependent on developments and politics in neighboring Nigeria. The inauguration of Niger's oil refinery in 2011 coincided with the IMF demanding the 
rol stations) in old one liter whiskey bottles at roadside stands. Those who buy at the stations are mostly state officials who receive petrol vouchers, development projects or transport companies. Here, it is important to note that the newly opened petrol stations are mostly owned by the same individual Nigerien businessmen who started the transport companies and who have, by now, built vertically integrated corporations. Their firms (e.g. Rharous, Bazagor, Escadrille, Oriba, NigerOil) are not part of the Groupement des Professionnels du Pétrole (Total and OiLibya) that in 2010 still controlled a $77 \%$ market share in Niger. These new companies thus enabled the acquisition of the so-called 'national content' in the Nigerien oil industry by pushing foreign oil businesses out of the market. Today, OiLibya only operates 18 petrol stations in Niger, 10 of which are located in Niamey. Total runs about 70 petrol stations, approximately 30 of which are currently leased from NigerOil.

The integrated upstream and downstream deal is not the only infrastructure investment by Chinese companies in Niger. Chinese companies have also invested in road and bridge construction, fiber optics, telecommunications and hotel construction, as well as water supply. By 2014, China had become the largest provider to Niger, its second largest trading partner, with a trade volume of \$US300 million, and with total investments in Niger reaching \$US4.7 billion, supported by the presence of 30 Chinese companies employing about 6000 Nigeriens (Souleymane 2015). In order to access the natural resources that it lacks at home, over the past decade, generous credit lines for infrastructure projects, especially in the extractive industries, have become a recurrent feature of Chinese engagement in Africa. This has resonated well in many African countries, which felt and feel that their Western partners

government of Nigeria end their fuel subsidies, so that the fuel price on the black-market in Niger rose to 600 FCFA/liter for a short-time. However, due to large protests in Nigeria, then Nigerian president Jonathan Goodluck had to partly reinstall the fuel subsidies, so that the fuel price in the streets of Niger went down again to 450 FCFA/ liter. With the regime change from Goodluck to Muhammadu Buhari, the new president sacked the whole board of the state-run Nigerian National Petroleum Company (NNPC), and resumed the operations of Nigeria's oil refineries in September. The fuel price in Niger decreased to 250 FCFA/liter for a short time in September 2015, before skyrocketing to 750 FCFA due to fuel shortages in Nigeria. Nevertheless, even if the street fuel price is higher than at the petrol station, most Nigeriens buy from roadside stalls due to personal attachments with individual street vendors, habits, mutual trust relations and credit facilities. neglected infrastructure development for decades (Alves 2013). ${ }^{9}$

In contrast, a recently published World Bank study on the petroleum product markets in Sub-Saharan Africa concluded that the small size of African markets (Niger is one of their examples) make the development of the downstream petroleum sector uneconomic. As a rule of thumb, the bank calculated that a refinery size of $100,000 \mathrm{bpd}$ (vs. 20,000 bpd in Niger) was needed for economic profitability. Moreover, the economic unsustainability of these small producers was exacerbated by problems in other sectors in Africa like electricity supply and poor infrastructures (World Bank Group 2010, 33). Instead of suggesting the construction of this lacking infrastructure, the World Bank report suggests 'cutting' the existing production linkages. Existing refineries in Africa should be closed because of their inefficiency and lack of competitiveness, as they would pose the burden of additional costs on petroleum products in Sub-Saharan African countries (ibid., 39). In addition, the report classified the consumption linkages that result from the new job and income possibilities of oil refineries as negligible. Although this is true for the operational phase of the oil refinery, which has 548 staff at their headquarters (265 Nigeriens and 283 Chinese), the argument ignores three important dimensions of consumption linkages. Firstly, in the three year construction of the oil wells, refinery and pipeline, several thousand Nigerien workers were recruited, making the oil sector by far the largest single employer in eastern Niger. Secondly, income redistribution in social networks as a form of social security system leads to a situation in which several members of the family, friends and the neighborhood live off the salary of one oil worker. A formal salary in Niger has thus a large multiplier effect for poverty reduction and social security. Thirdly, the installation of the upstream and downstream oil industry associated with the informal economy in $\mathrm{Ni}$ ger thereby provided additional job opportunities. The new business in transport prompted, for example, a local businessman in Zinder to open a private parking area outside the city. This area is managed by the transport drivers' union, and attracts retail dealers, petty traders, sex workers and service providers from the larger West African sub-region, all trying to sell their products to the hundreds

9 The granting of cheap loans could also be classified as a governance strategy to create dependencies and the possibility of future political interference, as it has often been described for 'Western' politics and the production of the Third World debt crisis (Graeber 2011). If the African states are not able to repay their massive loans, the Chinese government might take control of these countries by virtue of their financial power. It might thus be that history is repeating itself, only in a different guise. 
of truckers who wait days or even weeks for the call to load their road tankers at the oil refinery. In addition, in anticipating the coming of oil in Niger after the signing of the oil contract in 2008, a construction boom took place: new houses, especially villas, were built, as well as hotels by the country's elite (politicians and businessmen). These projects employed hundreds of subworkers, carpenters and bricklayers in the towns of Niamey, Zinder and Diffa. Furthermore, Nigerien market traders supply Chinese food providers with vegetables, meat, fish and beverages. However, as many of the Nigerien oil workers lost their jobs after the end of the construction phase, and many of the newly constructed houses in Zinder are still waiting to be filled, little can be said about the sustainability of these Chinese promoted and, of course, still tentative linkages in Niger.

On the ground, the practice of Western multi-national oil companies in the context of neoliberal capitalism is characterized by the growing importance of 'corporate social responsibility' (CSR) (engagement in local development programs, communication with local authorities, training and education campaigns of the local population) that is increasingly replacing older forms of 'corporate philanthropy' (i.e. paternalistic redistribution patterns or 'gift culture' - the distribution of cash, foodstuffs and sanitary products to the local population) (Rajak 2011; Shever 2010; for a review article on CSR see Watts 2005). These forms of corporate engagement are intended to create a stable and safe economic environment, thereby disempowering local populations and delegitimizing their resistance (Barnes 2005; Kemedi 2003), as well as presenting a positive image to shareholders and consumers (Fleshman 2002). The growing importance of CSR, however, has to be understood in the context of so-called 'ethical capitalism' (Žižek 2011), in which new forms of ideology emerging in the West, such as the moralization of consumption, have directly affected corporate strategies. Žižek argues that whereas philanthropy was the dominant mode of redistributing profits of capital accumulation in the age of industrial capitalism, today philanthropy is increasingly being replaced by 'ethical consumption' itself (ibid.). In contrast, although Chinese state companies have started to meet global standards by enacting laws and regulations, the companies show little commitment to implementing them (Tan-Mullins 2014). However, in competition with Western multinational oil companies, the Chinese state and its companies are highly capable of learning and adapting (at least rhetorically) to global standards. A look at CNPC's website demonstrates that China is highly aware of its need to communicate its corporate responsibility to the public. Here, they display their responsibility to the environment, health, safety, and public welfare. However, looking at Chinese state companies' social engagement in Niger, their activities display the classical paternalistic redistribution patterns of 'corporate philanthropy'. Firstly, SORAZ engaged in about 30 philanthropic activities in Zinder, including the construction of schools and water wells, the donation of 50 tons of cereals, a contribution to the local government to solve the problem of water supply, the distribution of barrels to the local population neighboring the oil refinery, and financial contributions to several commemorative events and public institutions. Secondly, the CNPC has engaged in philanthropic activities in Diffa such as the construction of or contributions to treatment centers, water wells and schools. Moreover, in regard to the involvement of local authorities and the local population, Chinese state-owned oil companies seem to mainly act directly on the level of state-to-state cooperation. In Niger, administrative chiefs and authorities from regional state institutions such as the regional directions of the oil ministry, the ministry of environment and the labor inspectorates in Zinder and Diffa all complain that they are neither involved in any administrative issues related to oil production, nor would they have enough political leverage once they notice a breach of regulations. Instead of communicating with local authorities, all oil related issues are directly negotiated between the CNPC and state representatives of the host government.

Processes of standardization within the oil industry have been a major analytical focus in attempts to explain capitalist exclusion and inclusion within 'technological zones' (Barry 2006). It seems possible that lower standards allow for greater possibilities of including so-called 'national content', or in other words, the manifold linkages with the oil zone. With the 'financialization of accumulation', the Western oil companies became publicly traded firms, and thereby dependent on shareholder value, insurance modalities, credit approvals and high oil prices (Labban 2010). Indeed, Western oil companies often explain their reluctance to award contracts to local companies by referring to global standards of security, health and the environment, and arguing for their need to meet the standards due to stakeholder value and the oil companies' (re)insurance. The standards gap has been identified as a serious barrier to local content, and has caused controversies between Western and local companies, with the latter crying foul over willful exclusion from the industry (Witte 2014). It seems fair to assume that within the Chinese oil zone, a broader assemblage of economic elements, including African trade, is permitted to associate more easily and informally than with their Western counterparts. This makes it possible to proceed with 
low-cost production, and thus to economically exploit less profitable oil fields like those in Niger. Indeed, the conflict between SORAZ and SONIDEP shows that there are capitalist processes at work in both Western and Chinese oil production. In the case of Sudan for example, Patey (2013) notes that although they are state-owned, Chinese (and Indian) oil companies are not simply agents of state interests, but do indeed pursue corporate strategies of profit-maximization. Taylor further argues that 'oil companies from state capitalist systems have lower labor costs, stiff profit margins [often less than $10 \%$ vs. $15-25 \%$ of Western corporations] and rapid project completion [...that...] gives them a strong competitive edge' $(2014,350)$. Finally, building on low-cost production, Chinese oil companies pay African workers significantly lower wages and accommodate them in poorer housing than Western oil companies.

To summarize, the Chinese oil zone has enabled the government of Niger to politically generate manifold 'linkages' within the national territory (in Hirschman's (1981) sense of linkages). It is therefore not the nature or materiality of oil per se that is the root cause of the 'missing linkages' or 'enclave economy', as resource curse theorists would have it, nor is it a global capitalism as Marxists would argue (cf. Altvater 2013, 20), but rather, it is the particular form of capitalism which is most relevant. I argue that the 'missing linkages' are the effect of a Western neoliberal capitalism. In contrast, a Chinese state capitalism - that is, not neoliberal (Nonini 2008) - allows for the build-up of these very linkages. These findings do not support the common notion of a 'ruthless' and 'exploitative' Chinese strategy. It may well turn out that - going along with Rogers' (2014) deliberations on 'petrobarter' - that this more encompassing approach would be more likely to prevent the downward spiral of economic decline and poverty defined by the notion of the resource curse. Niger experienced a GDP growth in 2012 of $11.8 \%$ which is said to be overwhelmingly due to the refinery. Indeed, a first quantitative study on the economic impact of refining capacities of oil-producing countries as a core characteristic of the Chinese mode of oil investments shows a robust positive correlation (Baur 2014). However, the extension of the Chinese oil zone could be interpreted as another type of territorial-spatial control. In the entanglement of capitalism and imperialism, the Chinese oil zone merely affords a different form of domination than the oft described petro-imperialism of Western oil empires. It is thus not a question of either development or imperialism, but a 'both/and' understanding that I argue for, thereby acknowledging the emergence of a new Chinese variety of imperialism, albeit one that may offer greater potential for broader economic growth in Africa (Ovadia 2013).

\section{Assembling political rhetoric and culture - constituting 'soft power'}

After signing the oil contract with CNPC, the political entourage of Niger's then president Mamadou Tandja launched a political campaign called Tazartché (Hausa for "Continuation") at the oil refinery's foundation stone ceremony in 2008. Tazartché was designed to change the constitution, allowing Tandja's reelection for a third term. ${ }^{10} \mathrm{In}$ this political campaign, the history of unsuccessful oil exploration in Niger took center stage. Tandja was portrayed as the father of oil production, a man who's 'strength' and 'pragmatism' had allowed Niger to become an oil producing country. According to this political narrative, the Western oil companies that had undertaken oil exploration for 50 years had wanted to prevent Niger from becoming an oil producer in order to keep the oil as a future reserve. Thus, they had not conducted real exploration activities, nor had they announced the true quantity of oil reserves in Niger. Tandja was thereby portrayed as a strong leader able to resist neocolonial interference. Furthermore, his 'pragmatism' would perfectly match with China's pragmatic reputation and 'non-interference'. In response to Tazartché, the political opposition addressed the international community and called for sanctions against the state of Niger by organizing demonstrations for democracy. The call for democracy internationally evoked the idea of the 'resource curse' to shape public sentiment: Since Niger had oil now, the country was on the road to dictatorship! Indeed the opposition forces succeeded shortly afterwards, with the enactment of international sanctions against the Tandja government - namely, the suspension of the Economic Community of West African States (ECOWAS) and of economic partnerships by the EU, IMF, the World Bank and many Western countries. Indicating his determinism to stay in power with the help of China, Tandja reacted to the sanctions with a nationalist discourse, stating that ' $i l$ a deux cordes à son arc et que si l'une casse il y a l'autre', (Grégoire 22 février 2010). ${ }^{11}$

China puts much effort into its oil diplomacy, building on ideas of 'non-interference' and 'equal partnership'. It

10 Although Tazartché was launched at the ceremony for the laying of the foundation stone at the oil refinery on 27 October 2008, newspaper articles and rumors in 2005 show that the idea and planning of Tazarchté had already begun in 2005, if not earlier (see also Keenan 2005). As such, it should not be mistaken for an attempt to access the future oil rent (cf. Grégoire 2010).

11 English: 'There are two strings to his bow, if one should break, there is always the other'. 
proclaims 'south-south cooperation' in contrast to 'northsouth cooperation', which according to China, builds on Western paternalism, direct intervention, imperialism or even neo-colonialism (Taylor 2006). Chinese energy politics are portrayed as development strategies for Africa, in much the same manner that Western diplomacies portray their energy politics. In contrast to Western political rationalities which demonize China's engagement for its supposedly selfish interests, and its disregard for human rights as well as environmental and social responsibility, China claims to satisfy not only their own needs but also those of the African populations. This approach is popularly termed a 'win-win relationship' which the West, from a Chinese perspective, has completely failed to achieve until today (Jiang 2009). Furthermore, in building up radio stations in Niger and indeed throughout Africa to achieve popular consent for its (energy) politics among African populations, China uses the same 'soft power' as the West to achieve their ends in energy security (Luther 2011). However, whether China's oil diplomacy turns into 'soft power' depends on the subjectification of Chinese oil diplomacy by African elites and African populations more generally (Fijałkowski 2011). I argue that in associating China's oil diplomacy with Tandja's project for constitutional amendment, the Chinese-Nigerien political rhetoric increasingly became a kind of 'soft power'. Whereas Western politics are seen in Nigerien public national discourse as paternalistic, neo-colonial and ineffective in regard to development issues, Chinese politics in Niger are not only portrayed but also perceived in the national public discourse as an 'equal partnership' and a 'win-win situation' for both nations. In doing so, China avoids accusations of neo-colonialism. Indeed, this fits into the larger picture, with China and its engagement in Africa largely rated positively in popular African discourses (Wike/ Stokes/Poushter 2015). However, it seems that the translation of China's soft power shows fractions on the local level. Those people who work directly with the Chinese or were harmfully affected by oil production, like oil workers and parts of the population in Zinder and Diffa, argue that Western oil companies paid higher wages, treated them more equally, implemented better security standards, and involved the neighboring population in development programs. In contrast, these groups tend to perceive and portray the Chinese as 'hard-working donkeys', 'outlaws', 'masters of corruption', 'xenophobes' or even 'racists'.

On 18 February 2010 Tandja was overthrown by a military coup led by Commander Salou Djibo. This was long before the first barrel of oil had been produced. Djibo said his aim was to turn Niger into an example of democracy and good governance. It is important to note that with the emergence of the neoliberal good governance discourse that came to dominate Western development policies in the 1990s, the blame for deepening poverty exacerbation through oil production was laid on 'bad institutions' in the Global South. The neoliberal good governance discourse has therefore reduced the model of the 'resource curse' to one of 'governance failure'. According to this discourse, the resource curse formula of resource extraction + bad governance $=$ poverty exacerbation, has to be replaced by one of resource extraction + good governance $=$ poverty reduction (Pegg 2005). The resource curse then, it is argued, can be beaten by policy intervention through the promotion of good governance mechanisms and institution building (Humphreys/Sachs/Stiglitz 2007). The neoliberal good governance discourse was articulated in policy programs which were implemented across the globe. National governments and NGOs became engaged with international institutions like the International Monetary Fund (IMF) and the World Bank, while campaigns such as Publish What You Pay (PWYP) or the Extractive Industries Transparency Initiative (EITI) were developed as transparency mechanisms and to promote good governance (Weszkalnys 2011). PWYP Niger was founded in 2006, but Niger did not complete validation of the EITI criteria until March 2011 (under Djibo). Within a year of his rule, Djibo had organized new elections that saw the former political opposition come to power under Mahamadou Issoufou. Issoufou drew heavily on the neoliberal version of the 'resource curse' in his inaugural speech. Building on the idea that 'bad governance' is the root cause of resource conflicts, he tried to reassure an international audience of his commitment to 'good governance' and 'transparency' in the resource sector. With this move, Issoufou wanted to regain Western sympathies, and end the international sanctions enacted under Tandja.

In general, Western (oil) diplomacy is based on 'freedom discourses' such as freedom of press, freedom of speech, human rights, and democratization. Many journalists and academic studies portray Chinese energy politics in Africa as disregarding human rights, security, and environmental standards as well as boosting authoritarianism and corruption. Chinese energy politics in Africa are therefore linked to, or are even made responsible for, a 'second' resource curse: the Chinese are accused of violating the underlying principles of development, democracy, and human rights. However, Western criticism of human rights violations is selectively deployed when it serves Western interests. Western governments and companies provide a wide array of external support to 'well-oiled regimes', with great efforts put into anticipating and responding to potential criticism of their support for these 
regimes (White/Taylor 2001). However, in contrast to China's oil diplomacy, the translation of Western transnational governmentality in Niger mainly fails, because Western politics are widely portrayed and seen as neo-colonial (Schritt 2013). Discourses on Western neocolonialism have frequently triggered protests against AREVA/France in Niger, and they were also one factor that drove the 'protests against Charlie Hebdo’ in January 2015 (Schritt 2015). We should therefore be cautious about Ferguson's and Gupta's (2005) argument that Western transnational governmentality mainly succeeds by bypassing African states and directly cooperating with NGOs. Whereas Western transnational governmentality in Niger has largely failed, and national NGOs are often perceived by the population as vehicles of self-enrichment of the national elite to secure financial flows, China's transnational governmentality has mainly succeeded - at least in public national discourses - by being associated with national Nigerien political projects.

\section{Assembling geopolitics and the military - constituting 'crude power'}

In 2013, new Nigerien President Mahamadou Issoufou agreed to the installation of a drone base with 120 US-American soldiers in Niamey. At the US-Africa summit in July 2014 in Washington, he granted further permission to open a second drone base in Agadez, home to Niger's uranium mines, which are exploited by French company AREVA. From this base, the USA - alongside France, with whom they have increasingly started to cooperate with in the fight against terrorism - can strike Islamist groups in the Sahel-Saharan region. Similarly, on 23 October 2014, the French government started construction on a military base at the fort of Madama on the northeast frontier of $\mathrm{Ni}$ ger, close to the border with Libya. From there, it aims to strike against jihadist groups in the Sahara. Both nations have long advocated for military bases in Niger, but their calls had been refused by consecutive governments. It is important to note that in 2002, in the aftermath of 9/11, the USA launched a special program called Pan Sahel Initiative (PSI). The program was established to fight the threat of terrorism in the trans-Saharan region by training government troops from Mali, Mauretania, Niger and Chad. With the launching of the PSI, around 400 US rangers were sent to the Chad-Niger border regions. ${ }^{12}$ The PSI ended in 2004, and was extended in 2005 by the Trans-Sahara Counterterrorism Initiative (TSCTI) to incorporate eleven countries from the region in the fight against terrorism. In 2008, TSCTI was incorporated in AFRICOM, which covers the whole of Africa (except Egypt) under a joint military command headquartered at Kelly Barracks in Stuttgart, Germany. It seems that despite historical competition between France and the USA for Africa, they have increasingly started to cooperate (Keenan 2009). After 9/11, the US justified expansion of the Western oil zone into Africa by promoting a discourse on energy security that combined the peak-oil hypothesis with the fact that the remaining oil reserves lie outside US-American territory, in countries they argued were prone to terrorist activities (Labban 2011). The discourse thus drives the expansion of open markets in combination with a militarization of global space to 'allow the free flow of commodities and investment capital' (ibid., 326). The USA established their new Africa command (AFRICOM) as a political strategy to secure energy resources, especially oil, and to combat growing Chinese interest in the continent's resources (Volman Dec., 2003, 2009; Besteman October 2008; Besteman 2009; Keenan 2008). The consequences for African states are manifold, as Sandra Barnes (2005, $6 \mathrm{ff}$.) argues. On the one hand, the creation of military bases and lily pads' (bases for military equipment) enforce the US military presence on the continent, and on the other hand, the implementation of military training, the financing of counterterrorism and the supply of arms promote military capacity building amongst those African countries loyal to US interests. However, Western mainstream media has largely remained silent about AFRICOM, and the subtle and shadowy militarization of the continent (ibid., $15 \mathrm{ff}$.). Stephen Reyna (2009) holds that a 'global warring' is at work, in which the US seeks to reproduce their capitalist oil-empire whenever the American oil-supply is endangered (see also Klare 2001, 2004). However, Western governments are only one element amongst many others within an assemblage, and it may well turn out that what seems at first sight to be a 'war for oil' (in Iraq), was instead a 'war for no oil', in order to avoid a drop in oil prices and to protect oil companies' high profits (Palast 2013).

Although China puts most of its overseas efforts into 'soft power', its military presence has grown constantly

12 Most of the soldiers were, in fact, 'contractors' from private military companies (PMC), as the former US-state's military responsibility had been outsourced in accordance with neoliberal political rationality, and thereby turned into a multibillion dollar industry (Keenan 2008, 17/20 ff.). 
over the past decades, and especially since 1990, when it agreed to join in UN peacekeeping responsibilities. China currently has 14 times more peacekeepers in Africa then the USA (1645 compared to 118 soldiers). In addition, China tries to protect their overseas investments in Africa by arming and training the armies of their host countries to create political stability. Degang Sun (2015) sees China as employing a 'soft' military overseas approach that builds on 'the temporary deployment of armed forces for overseas military exercises, as well as the deployment of military patrols, peacekeeping forces, military trainers, and consultants'. In contrast, Sun argues that the USA employs a 'hard' military strategy which includes military bases within the borders of African countries, the right to access and use the bases freely while enjoying extraterritorial rights and privileges, and the support of military efforts including combat, command, surveillance, and intelligence-collecting operations. Hillebrand and Closson $(2015,140)$ predict that by 2020 'the weak African nations, which eagerly accepted Chinese aid and investment in the first decade of this century, will come under increasing pressure as China begins requesting a military presence to protect its substantial investments and to discourage other outside interests'. Indeed, China has already started to request a permanent military presence in Africa, signing their first military agreement in February 2014, which allows the Chinese navy to use Djibouti port. Although the growing Chinese military presence in Africa is seen by most political analysts as a direct threat to US geostrategic interests, it also allows for potential cooperation, as the development of the historical competition between France and the USA in Africa into partners of convenience appears to show. Finally, it is worth noting that 'soft' governance technologies of subjectification do not eradicate 'hard' governance technologies of coercion and force, but rather coexist with them. The historical and social reality is therefore not only a process of (neoliberal) rationalization; instead, it is a 'mix ratio' of freedom, self conduct, disciplinary subjugation, and force (Lemke 2000, 41). From a governmentality perspective, we might therefore argue that if the translation of transnational governmentality into 'soft power' fails, this failure might legitimize 'hard' governance technologies of coercion (e.g. the economic sanctions against the regime of Tandja) and force (e.g. militarization of Niger) (Schritt 2013).

\section{Zones of capitalisms}

From the perspective of a deep ontology like that of classical Marxist approaches, the capitalist mode of production per se is the underlying structure or deeper 'base' on which the legal, political and ideological 'superstructure' is built. Michael Watts (2012), for example, whose academic work can be classified as a 'rigorous and wide-ranging theoretical engagement with Marxian political economy' (Perreault 2011, 323) has theorized the 'oil complex' as a regime of accumulation, with a permanent frontier of dispossession that violently extends in order to establish the conditions for new capital accumulation. The majority of social science approaches to oil extraction generalize oil infrastructures and the workings of capitalism by pointing to the enclave nature of oil production, and the process of the oil companies 'walling themselves off' from their socio-economic and political surroundings within host countries, in order to allow smooth capital accumulation in a context of global capitalism (Ferguson 2005, Appel 2012a, 2012b, Donner 2011; Zalik 2009; Yessenova 2012). These authors have thus generalized the working of the oil industry as if there is only one form of petro-infrastructure and only one form of neoliberal or Anglo-American capitalism on a global scale. In contrast, debates on capitalist diversity like the 'comparative capitalism' (CC) and the 'varieties of capitalism' (VoC) literature emphasize the significant diversity within capitalism. In doing so, they criticize the simplistic assumptions of globalization theses 'which predicted a post-Cold War convergence of all institutional forms of capitalism towards one supposedly superior market-liberal Anglo-American model' (Bruff/Ebenau 2014, 5). However, by pointing towards the institutional configurations rather than the wider spatial, socio-cultural, political, economic and technological relations in which institutions are entangled, the comparative capitalism literature seems to fall back onto 'national container' assumptions (for an overview see Bruff/Ebenau 2014).

In contrast to this literature, I make use of the 'relational ontology' of assemblages in order to conceptualize 'oil zones' not as a superstructure of global capitalism - like a 'deep ontology' would - but to see 'varieties of capitalism' rather as specific properties of trans-territorial assemblages of heterogeneous elements. By engaging the empirical example of Western and Chinese oil zones' entanglements in Niger with the broader literature on the oil industry and 'China in Africa', I identify the following heterogeneous elements that are assembled within the process of bringing oil production into life: petro-infrastructures, economic theories, oil diplomacies, lending institutions, corporate 
Table 1: Oil zones.

\begin{tabular}{lll}
\hline Heterogeneous elements & Western petro-assemblages & Chinese petro-assemblages \\
\hline Petro-infrastructure & Enclave industrialization & Upstream and downstream industry \\
\hline Economic theories & $\begin{array}{l}\text { (Neo)classical economic theory: } \\
\text { 'governance curse' }\end{array}$ & $\begin{array}{l}\text { Linkage approach; } \\
\text { allows the build-up of so-called backward and } \\
\text { forward linkages }\end{array}$ \\
\hline Oil diplomacy & $\begin{array}{l}\text { Selective deployment of 'freedom' discourses } \\
\text { Demonizing China for a 'second' resource curse }\end{array}$ & $\begin{array}{l}\text { 'Equal partnership', 'win-win relationship', } \\
\text { 'south-south cooperation', 'non-interference' } \\
\text { Demonizing the West for neocolonial interference }\end{array}$ \\
\hline $\begin{array}{ll}\text { Institutions } \\
\text { Corporate structure }\end{array}$ & Worldbank, IMF, PWYP. ITIE, international NGOs & EXIM Bank, China Development Bank \\
\hline $\begin{array}{l}\text { Corporate practice and } \\
\text { regulations }\end{array}$ & Transnational oil companies & State-owned national oil companies \\
\hline Contractual agreements & Corporate Social Responsibility, global standards & $\begin{array}{l}\text { Corporate Philanthropy, state-to-state coopera- } \\
\text { tion, low standards, low-cost production }\end{array}$ \\
\hline Military strategies & $\begin{array}{l}\text { Mixed } \\
\text { (often concessions, PSAs, service contracts) }\end{array}$ & $\begin{array}{l}\text { Mixed } \\
\text { (mainly PSAs, joint-ventures) }\end{array}$ \\
\hline
\end{tabular}

structures, corporate practices and regulations, contractual agreements and military strategies (see table 1).

Regarding oil zones as trans-territorial spaces of assemblage, I suggest conceptualizing the Western and the Chinese oil zones as different entities with specific characteristics which enact causal powers. By causal powers I refer to specific inward oriented (governmentality and necessity of profit-maximization inherent to capitalism) and outward oriented forces (transnational governmentality and capitalist process of accumulation). In the Western petro-assemblage, the connection of heterogeneous elements like oil concessions, transnational oil companies, enclave infrastructures, international donor organizations, freedom discourses, a demonization of China, the militarization of global space, the setting of global standards and neoclassical economic theories produce a form of neoliberal 'militarized ethical capitalism' in which new forms of ideology emerge (like the moralization of consumption) that directly affect corporate strategies (like Corporate Social Responsibility). In contrast, the Chinese petro-assemblage incorporates vastly different heterogeneous elements than the Western variant. As such, it has shaped a capitalist zone that is not neoliberal, but combines elements of 'socialist planning' and 'social engineering' (Jeffreys/Sigley 2011) into a 'developmental state model' or 'state capitalism' (Taylor 2014). Its causal powers rather resemble logics of capital accumulation in 'industrial capitalism' that allow for the build-up of manifold linkages. However, globalization does indeed give rise to ever more connections through global markets. As- semblages are therefore not to be understood as totalities that could be characterized like organisms by relations of interiority, but rather emerge from relations of exteriority between self-contained parts (DeLanda 2006). Western and Chinese oil zones thus emerge as wholes in relational, overlapping, conflicting, competing and cooperative form. Although the Western and Chinese oil zones are competing for African oil, this competition does not necessarily exclude exchange and cooperation. Nor does this competition inherently lead to violent conflict and war, though it may be one possible outcome. Furthermore, the elements in the assemblages I have identified here are neither timeless nor set in stone, but are rather themselves part of dynamic processes of change. This is clear when one looks at companies' growing involvement in CSR activities, militarization, or the corporate strategies of profit maximization by Chinese state-owned oil companies.

\section{Conclusion: the petro-political configuration in Niger}

I started out this article by looking at how Chinese and Western oil zones are entangled within the Nigerien context. I showed that these entanglements have triggered the emergence of a particular configuration of politics and oil production in Niger, which I call 'the petro-political configuration'. Using Niger as an example, and situating it in a wider context by drawing on the vast literature on 
the oil industry and 'China in Africa', I have sketched out two trans-territorial spaces of assemblage, a Western and a Chinese 'oil zone', each enacting particular (capitalist) properties.

Firstly, I showed that oil was not produced in Niger despite the presence of multi-national oil companies since 1958. This was due to a Western oil zone that socio-spatially produced scarcity in order to avoid over-supply and a subsequent drop in oil prices. The oil was left in the ground due to a market economy that classified oil production in Niger as uneconomic. It was the 'Chinese factor' that finally enabled the Nigerien economy to build forward and backward linkages, thereby tentatively overcoming enclave industrialization, and ensuring the retention of part of the energy produced in Niger for use within the national territory. Whereas the literature on the oil industry suggests that its enclave character is an inevitable by-product of its production and global capitalism, the Nigerien case study shows that the Chinese oil zone has indeed allowed for manifold - although fragile - linkages with the African economy, and the tentative establishment of 'national content' within the oil industry.

Spatially, it would be fair to say that the Western oil zone has developed the materiality of oil as a 'point source' resource (Auty 2001; Le Billon 2001, 570) into a 'point resource strategy' of 'enclave industrialization', creating 'points of profit' for transnational capital in a tiny area of the continent considered Afrique utile. Only minimally does the Western oil zone extend out from the 'enclave' of oil extraction, mainly in the construction of access roads and oil-company related transport. In contrast, the Chinese oil zone has shown that the natural feature of oil as a 'point source' resource does not necessarily translate into a 'point resource strategy' of 'enclave industrialization' and 'points of profit'. It is able to extend out on a much larger scale, establishing the different linkages which Hirschman (1981) mentions in his 'linkage model', and thereby allowing parts of so-called Afrique inutile to also become Afrique utile.

The Western and Chinese oil zones are further entangled with the specific political and socio-cultural context in Niger. Firstly, by associating China's oil diplomacy into former president Tandja's project to change the constitution, China's political rhetoric became a kind of 'soft power' in Nigerien public national discourse, something the Western political rhetoric of freedom discourses has long failed to achieve. At the same time, this failure of Western transnational governmentality in Niger has legitimized means of coercion and force visible in AFRICOM. While China is also increasingly investing in military means on the continent and therefore 'closing the gap', its military footprint is still small in comparison to that of France and the USA.

Regarding the assemblage of spatial, economic, political and socio-cultural aspects, the differences are due to the particular characteristics of the two zones. The Western oil zone assembles heterogeneous elements such as multi-national oil companies, enclave industrialization, freedom discourses, corporate social responsibility, AFRICOM and monetary institutions like the IMF and the World Bank, combined with neoclassical economic theory into a neoliberal form of militarized ethical capitalism. In contrast, the Chinese oil zone assembles their own lending institutions (EXIM bank and China Development Bank) and visions of economic theory, state-owned corporations, upstream and downstream petro-infrastructure, political rhetoric of 'equal partnership', 'win-win relationship' and 'non-interference', and 'soft' military strategies into a form of state capitalism that is not neoliberal. Understanding the particular capitalist properties of these two different zones helps to lay bare the varying spatial, economic, political and socio-cultural transformation processes induced by entanglements of these zones within the Nigerien context. This case study reveals how different capitalisms and their articulations with local elements lead to the emergence of complex and unique 'petro-political configurations' which cannot be sufficiently understood using simplistic notions about neoliberalism as the single global force shaping the world.

\section{References}

Aglietta, M. (1976): Régulation et crises du capitalisme. L'expérience des États-Unis. Paris.

Altvater, E. (2013): Der unglückselige Rohstoffreichtum. Warum Rohstoffextraktion das gute Leben erschwert. In: Burchardt, H.-J./Dietz, K. (Hrsg.): Umwelt und Entwicklung im 21. Jahrhundert : Impulse und Analysen aus Lateinamerika. Baden-Baden, 15-32.

Alves, A. C. (2013): China's 'win-win' cooperation: Unpacking the impact of infrastructure-for-resources deals in Africa. In: South African Journal of International Affairs, (20)2, 207-226.

Appel, H. C. (2012a): Offshore work: Oil, modularity, and the how of capitalism in Equatorial Guinea. In: American Ethnologist, (39)4, 692-709.

Appel, H. C. (2012b): Walls and white elephants: Oil extraction, responsibility, and infrastructural violence in Equatorial Guinea. In: Ethnography, (13)4, 439-465.

Appel, H./Mason, A./Watts, M. (Hrsg.) (2015): Subterranean estates. Life worlds of oil and gas. Ithaca, United States.

Apter, A. H. (2005): The Pan-African nation. Oil and the spectacle of culture in Nigeria. Chicago. 
Augé, B. (2011): Les nouveaux enjeux pétroliers de la zone saharienne. In: Hérodote - revue de géographie et de géopolitique, 142, 183-205.

Auty, R. M. (1993): Sustaining development in mineral economies. The resource curse thesis. London.

Auty, R. M. (2001): Resource abundance and economic development. Oxford, New York.

Barnes, S. T. (2005): Global Flows: Terror, Oil, and Strategic Philanthropy. In: African Studies Review, (48)1, 1-23.

Barry, A. (2006): Technological Zones. In: European Journal of Social Theory, (9)2, 239-253.

Barry, A. (2013): Material Politics. Disputes Along the Pipeline. West Sussex.

Baur, S. (2014): Refining Oil - A Way out of the Resource Curse? (= Working paper Series 2014).

Behrends, A. (2008): Fighting for Oil when there is No Oil Yet. The case of the Chad-Sudan border. In: Focaal, (52), 39-56.

Behrends, A./Reyna, S. P./Schlee, G. (Hrsg.) (2011): Crude domination. An anthropology of oil. New York.

Behrends, A./Schareika, N. (2010): Significations of oil in Africa or: What (more) can anthropologists contribute to the study of oil? In: Soumen Antropologi, (35), 83-86.

Bennett, J. (2010): Vibrant matter. A political ecology of things. Durham.

Besteman, C. (2008): 'Beware of those bearing gifts'. An anthropologist's view of AFRICOM. In: Anthropology Today, (24)5, 20-21.

Besteman, C. (2009): Counter AFRICOM. In: The Network of Concerned Anthropologists (Hrsg.): The counter-counterinsurgency manual : or, notes on demilitarizing American society. Chicago, 115-134.

Blumer, H. (1954): What is wrong with social theory? In: American Sociological Review, (19)1, 3-10.

Boyer, D. (2011): Energopolitics and the Anthropology of Energy. In: Anthropology News, (52)5, 5-7.

Boyer, D. (2014): Energopower: An Introduction. In: Anthropological Quarterly, (87)2, 309-333.

Bruff, I./Ebenau, M. (2014): Critical political economy and the critique of comparative capitalisms scholarship on capitalist diversity. In: Capital \& Class, (38)1, 3-15.

Callon, M./Latour, B. (1981): Unscrewing the Big Levitahan: how actors macro-structure reality and how sociologists help them to do so. In: Knorr-Cetina, K./Cicourel, A. V. (Hrsg.): Advances in social theory and methodology. Toward an integration of microand macro-sociologies. Boston, 277-302.

Charlick, R. B. (1991): Niger. Personal rule and survival in the Sahel. Boulder, Colo.

Collier, S. J./Ong, A. (2005): Global assemblages, anthropological problems. In: Collier, S. J./Ong, A. (Hrsg.): Global assemblages. Technology, politics, and ethics as anthropological problems. Malden, Mass, 3-21.

Coronil, F. (1997): The magical state. Nature, money, and modernity in Venezuela. Chicago, Ill., London.

DeLanda, M. (2006): A new philosophy of society. Assemblage theory and social complexity. London, New York.

Donner, N. (2011): Notes sur la dimension immunitaire des enclaves pétrolières. In: EchoGéo, 17.

Dorlöchter-Sulser, S. (2014): Wandel von Livelihood-Systemen im Spannungsfeld von Struktur und Handeln. Eine historisch angelegte Livelihood-Analyse von 1960 bis 2010 am Beispiel der Region Dosso, Niger. Berlin.
Ferguson, J. (2005): Seeing Like an Oil Company: Space, Security, and Global Capital in Neoliberal Africa. In: American anthropologist, (107)3, 377-382.

Ferguson, J./Gupta, A. (2005): Spatializing States. Toward an Ethnography of Neoliberal Governmentality. In: Inda, J. X. (Hrsg.): Anthropologies of modernity. Foucault, governmentality and life politics. Malden, Mass.

Fijatkowski, t. (2011): China's 'soft power' in Africa? In: Journal of Contemporary African Studies, (29)2, 223-232.

Fleshman, M. (2002): The International Community \& the Crisis in Nigeria's Oil Producing Communities. In: Review of African Political Economy, (29)91, 153-163.

Frynas, J. G./Paulo, M. (2007): A new scramble for African oil? Historical, political, and business perspectives. In: African Affairs, (106)423, 229-251.

Gaya, M. L. (2015): Vers où nous mène le <<roi»> pétrole? In: Les Afriques, 311, 52-59.

Gelb, A. H. (Hrsg.) (1988): Oil windfalls. Blessing or curse? New York. (=A World Bank research publication).

Ghazvinian, J. H. (2007): Untapped. The scramble for Africa's oil. Orlando.

Graeber, D. (2011): Debt. The first 5,000 years. Brooklyn, New York. Grégoire, E. (2010): Coup d'état au Niger : le président Tandja Mamadou chassé par l'armée. In: Hérodote - revue de géographie et de géopolitique. http://www.herodote.org/spip. php?article417

Hall, P. A./Soskice, D. (Hrsg.) (2001): Varieties of Capitalism. The institutional foundations of comparative advantage. New York.

Hecht, G. (2012): Being nuclear. Africans and the global uranium trade. Cambridge, Mass.

Hicks, C. (2015): Africa's new oil. Power, pipelines and future fortunes. London. (=African arguments).

Hillebrand, E. E./Closson, S. (2015): Energy, economic growth, and geopolitical futures. Eight long-range scenarios. Cambridge, Mass.

Hirsch, J. (1990): Kapitalismus ohne Alternative? materialistische Gesellschaftstheorie und Möglichkeiten einer sozialistischen Politik heute. Hamburg.

Hirsch, J./Jessop, B./Poulantzas, N. (Hrsg.) (2001): Die Zukunft des Staates. Denationalisierung, Internationalisierung, Renationalisierung. Hamburg.

Hirschman, A. O. (1981): A Generalized Linkage Approach to Development, with Special References to Staples. In: Hirschman, A. O. (Hrsg.): Essays in trespassing. Economics to politics and beyond. Cambridge, New York, 59-97.

Humphreys, M./Sachs, J./Stiglitz, J. E. (2007): Escaping the Resource Curse. New York.

Idrissa, K. (Hrsg.) (2001): Le Niger. État et démocratie. Paris. Idrissa, K. (Hrsg.) (2004): Armée et politique au Niger. Dakar. Innis, H. A. (1995): Staples, markets, and cultural change. Selected essays. . Montreal, Que.

Jeffreys, E./Sigley, G. (2011): Governmentality, governance and China. In: Jeffreys, E. (Hrsg.): China's governmentalities. Governing change, changing government. London, 1-23.

Jessop, B. (2007): Kapitalismus, Regulation, Staat. Ausgewählte Schriften. Hamburg.

Jiang, W. (2009): Fuelling the Dragon: China's Rise and It's Energy and Resources Extraction in Africa. In: The China Quarterly, 199, 585-609. 
Karl, T. L. (1997): The paradox of plenty. Oil booms and petro-states. Berkeley, Calif., Los Angeles, London. (=Studies in international political economy, 26 : Political science/ Economics/Latin American studies).

Keenan, J. (2005): Famine in Niger Is Not All That It Appears. In: Review of African Political Economy, (32)105/105, 405-407.

Keenan, J. (2008): US militarization in Africa. What anthropologists should know about AFRICOM. In: Anthropology Today, (24)5, 16-20.

Keenan, J. (2009): Al-Qaeda terrorism in the Sahara? Edwin Dyer's murder and the role of Intelligence agencies. In: Anthropology Today, (25)4, 14-18.

Kemedi, D. von (2003): The Changing Predatory Styles of International Oil Companies in Nigeria. In: Review of African Political Economy, (30)95, 134-139.

Klare, M. T. (2001): Resource wars: the new landscape of global conflict. New York.

Klare, M. T. (2004): Blood and oil: the dangers and consequences of America's growing petroleum dependency. New York.

Klare, M. T./Volman, D. (2006): America, China \& the Scramble for Africa's Oil. In: Review of African Political Economy, (33)108, 297-309.

Klimek, B. (2010): Ordnung ins spontane Chaos! Regulationstheorie regional, national, global. Marburg.

Labban, M. (2008): Space, oil, and capital. Abingdon, New York, NY. (=Routledge studies in international business and the world).

Labban, M. (2010): Oil in parallax: Scarcity, markets, and the financialization of accumulation. In: Geoforum, (41)4, 541-552.

Labban, M. (2011): The geopolitics of energy security and the war on terror: the case for market expansion and the militarization of global space. In: Peet, R./Robbins, P./Watts, M. (Hrsg.): Global political ecology. London, New York, 323-342.

Le Billon, P. (2001): The political ecology of war. Natural resources and armed conflicts. In: Political Geography, (20), 561-584.

Legg, S. (2009): Of scales, networks and assemblages: the League of Nations apparatus and the scalar sovereignty of the Government of India. In: Transactions of the Institute of British Geographers, (34)2, 234-253.

Lemke, T. (2000): Neoliberalismus, Staat und Selbsttechnologien. Ein kritischer Überblick über governmentality studies. In: Politische Vierteljahresschrift, (41)1, 31-47.

Luther, P. (2011): Genehm und gratis. In: Le monde diplomatique. 8.4.2011. http://monde-diplomatique.de/artikel/!305259

Mahamane, A. (2004): La naissance de l'armée national au Niger: 1961-1974. In: Idrissa, K. (Hrsg.): Armée et politique au Niger. Dakar, 45-92.

Moussa, O. (2012): Le pétrole nigérien. D’Agadem à la SORAZ. In: Sahel Dimanche 9.11.2012, 12. http://www.lesahel.org/index. $\mathrm{php} /$ component/k2/item/1651-le-petrole-nigerien--dagadema-la-soraz

Mitchell, T. (2011): Carbon democracy. Political power in the age of oil. London, New York.

Nonini, D. M. (2008): Is China Becoming Neoliberal? In: Critique of Anthropology, (28)2, 145-176.

Ovadia, J. S. (2013): Accumulation with or without dispossession? A 'both/and' approach to China in Africa with reference to Angola. In: Review of African Political Economy, (40)136, 233-250.
Palast, G. (2013): The Real Reason for the Iraq War. In: Vice magazine. 29.3.2013. http://www.vice.com/en_uk/read/ the-iraqi-war-wasnt-waged-for-oil-greg-palast

Patey, L. A. (2013): The new kings of crude. China and India's global struggle for oil in Sudan. London.

Peck, J./Theodore, N. (2007): Variegated capitalism. In: Progress in Human Geography, (31)6, 731-772.

Pegg, S. (2005): Can Policy Intervention beat the Resource Curse? Evidence from the Chad-Cameroon Pipeline Project. In: African Affairs, (105)418, 1-25.

Perreault, T. (2011): Micheal J. Watts. In: Hubbard, P./Kitchin, R. (Hrsg.): Key thinkers on space and place. 2. Aufl. Los Angeles, 454-460.

Rajak, D. (2011): In good company. An anatomy of corporate social responsibility. Stanford, California.

Reyna, S. (2009): Taking Place: 'New Wars' versus Global Wars. In: Social Anthropology, (17)3, 291-317.

Richardson, T./Weszkalnys, G. (2014): Introduction: Resource Materialities. In: Anthropological Quarterly, (87)1, 5-30.

Robinson, P. T. (1991): Niger: Anatomy of a Neotraditional Corporatist State. In: Comparative Politics, (24)1, 1-20

Rogers, D. (2012): The materiality of the corporation. Oil, gas, and corporatee social technologies in the remaking of a Russian region. In: American Ethnologist, (39)2, 284-296.

Rogers, D. (2014): Petrobarter: Oil, Inequality, and the Political Imagination in and after the Cold War. In: Current anthropology, (55)2, 131-153.

Rosen, A. (2015): An oil dispute in Niger is exposing big problems with Chinese investment in Africa. In: Business Insider. 30.09.2015. http://uk.businessinsider.com/niger-oil-and-chinese-investment-in-africa-2015-9

Ross, M. L. (2012): The oil curse. How petroleum wealth shapes the development of nations. Princeton, NJ.

Schritt, J. (2013): Transnational Governmentality of Energy Security after 9/11. Coup d'état, Terrorism, Militarization, and Oil in Niger. In: Colaguori, C. (Hrsg.): Security, life, and death. Governmentality and biopower in the post 9/11 era. Whitby, Ont, 193-244.

Schritt, J. (2014): Erdöl und Macht in Niger. In: Welttrends, (97), 46-52.

Schritt, J. (2015): The "Protests against Charlie Hebdo" in Niger: A Background Analysis. In: Africa Spectrum, (50)1, 49-64.

Schritt, J./Behrends, A. (forthcoming): 'Western' and 'Chinese' Oil Zones. Petro-Infrastructures and the emergence of new trans-territorial spaces of order in Niger and Chad. In: Engel, U./Müller-Mahn, D./Böckler, M. (Hrsg.): Spaces of Order: Adaptation and Creativity in Africa.

Sharife, K. (2010): La puissance nucléaire française et l'uranium du Niger. In: Pambazuka, 135. http://www. pambazuka.net/fr/ category.php/features/ 62512

Shever, E. (2010): Engendering the Company: Corporate Personhood and the "Face" of an Oil Company in Metropolitan Buenos Aires. In: PoLAR: Political and Legal Anthropology Review, (33)1, 26-46.

Sun, D. (2015): China's Soft Military Presence in the Middle East. Middle East Institute. 11.3.2015. http://www.mei.edu/content/ map/china\%E2 \%80\%99s-soft-military-presence-middle-east.

Tan-Mullins, M. (2014): Successes and Failures of Corporate Social Responsibility Mechanisms in Chinese Extractive Industries. In: Journal of Current Chinese Affairs, (43)4, 19-39. 
Taylor, I. (2006): China's Oil Diplomacy Africa. In: International affairs, (82)5, 937-959.

Taylor, I. (2014): Emerging powers, state capitalism and the oil sector in Africa. In: Review of African Political Economy, (41)141, 341-357.

van Vliet, G./Magrin, G. (2012): Une compagnie petrolière chinoise face à l'enjeu environmental au Tchad. Paris.

van Walraven, K. (2009): Decolonization by referendum. The anomaly of Niger and the fall of Sawaba, 1958-1959. In: The Journal of African History, (50)2, 269-292.

Villalón, L. A./Idrissa, A. (2005): Repetitive Breakdowns and a Decade of Experimentation: Institutional Choices and Unstable Democracy in Niger. In: Villalón, L. A./VonDoepp, P. (Hrsg.): The fate of Africa's democratic experiments. Elites and institutions. Bloomington, 27-48.Volman, D. (2003): The Bush Administration \& African Oil: The Security Implications of US Energy Policy. In: Review of African Political Economy, (30)98, 573-584.

Volman, D. (2009): China, India, Russia and the United States. The Scramble for African Oil and the Militarization of the Continent. 43. Aufl. Uppsala. (=Current African Issues).

Watts, M. (2004): Resource curse? governmentality, oil and power in the Niger Delta, Nigeria. In: Geopolitics, (9)1, 50-80.

Watts, M. J. (2005): Righteous oil? Human rights, the oil complex, and corporate social responsibility. In: Annual Review of Environment and Resources, (30)1, 373-407.

Watts, M. (2012): A Tale of Two Gulfs: Life, Death, and Dispossession along Two Oil Frontiers. In: American Quarterly, (64)3, 437-467.

Weszkalnys, G. (2011): Cursed resources, or articulations of economic theory in the Gulf of Guinea. In: Economy and Society, (40)3, 345-372.

White, G./Taylor, S. (2001): Well-Oiled Regimes: Oil \& Uncertain Transitions in Algeria \& Nigeria. In: Review of African Political Economy, (28)89, 323-344.

Wike, R./Stokes, B./Poushter, J. (2015): Global Publics Back U.S. on Fighting ISIS, but Are Critical of Post-9/11 Torture. Asian Nations Mostly Support TPP, Defense Pivot - but Also Value Economic Ties with China. 23.6.2015. http://www.pewglobal. org/2015/06/23/global-publics-back-u-s-on-fighting-isis-butare-critical-of-post-911-torture/

Witte, A. (2014): „A completely different beast“: Die Erdölindustrie in Uganda. Göttingen. (=Institutkolloquium Ethnologie).
World Bank Group (2010): Petroleum Product Markets in Sub-Saharan Africa. Comparative Efficiency Analysis of 12 Countries. http://www-wds.worldbank.org/external/default/ WDSContentServer/WDSP/IB/2011/04/15/000333037_20 110415023812/Rendered/PDF/611260ESW0whit1Efficiency0Study0121.pdf

Xinhua News Agency (2013): Niger : levée de boucliers des populations de Niamey face à la prolifération des stations d'essence (SYNTHESE). In: People's Daily Online, 16.04.2013. http://french.peopledaily.com.cn/96852/8208623.html

Yates, D. A. (1996): The Rentier State in Africa. Oil Rent Dependency and Neocolonialism in the Republic of Gabon. Trenton, NJ.

Yates, D. A. (2012): The scramble for African oil. Oppression, corruption and war for control of Africa's natural resources. London, New York.

Yergin, D. (1991): The Prize. The Epic Quest for Oil, Money, and Power. New York.

Yessenova, S. (2012): The Tengiz Oil Enclave: Labor, Business, and The State. In: PoLAR: Political and Legal Anthropology Review, (35) $1,94-114$

Zalik, A. (2009): Zones of Exclusion: Offshore Extraction, the Contestation of Space and Physical Displacement in the Nigerian Delta and the Mexican Gulf. In: Antipode, (41)3, 557-582.

Žižek, S. (2011): Living in the end times. London, New York.

\section{Bionote}

\section{Jannik Schritt}

Institute for Social and Cultural Anthropology, Georg August University of Göttingen, Theaterplatz 15, 37073 Göttingen, Germany, e-mail: jschrit@uni-goettingen.de

Jannik Schritt is a PhD researcher in a German Research Foundation (DFG) funded project on 'Oil and Social Change in Niger and Chad' at the Georg August University of Göttingen. He has published several articles on transnational governmentality, oil politics and protest movements in Niger. 